\title{
Correction: How common is clinically inactive disease in a prospective cohort of patients with juvenile idiopathic arthritis? The importance of definition
}

Dore M, Marlow C, Cares WM, et al. How common is clinically inactive disease in a prospective cohort of patients with juvenile idiopathic arthritis? The importance of definition. Ann of Rheum Dis 2017;76:1381-8.

Figure 1 was corrected online but the incorrect version appeared in the August print issue.

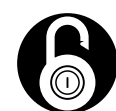

\section{OPEN ACCESS}

Open Access This is an Open Access article distributed in accordance with the Creative Commons Attribution Non Commercial (CC BY-NC 4.0) license, which permits others to distribute, remix, adapt, build upon this work noncommercially, and license their derivative works on different terms, provided the original work is properly cited and the use is non-commercial. See: http://creativecommons.org/licenses/by-nc/4.0/

(C) Article author(s) (or their employer(s) unless otherwise stated in the text of the article) 2017. All rights reserved. No commercial use is permitted unless otherwise expressly granted.

Ann Rheum Dis 2017;76:1784. doi:10.1136/annrheumdis-2016-210511corr1

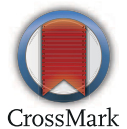

